\title{
Het schadefonds Van Vollenhoven
}

\section{Hoe om te gaan met gedupeerden van acute overheidsmaatregelen ten behoeve van de gezondheid of veiligheid}

\author{
Mr. C.N.J. Kortmann*
}

\section{Het Stint-drama}

Sinds 20 september 2018 weet iedereen wat een Stint is. Op die donderdagochtend weigerden de remmen van de elektrische bakfiets, waarmee een twaalftal kinderen met hun begeleidster op weg waren van de kinderopvang naar de basisschool. De Stint reed in de Braakstraat vlak bij station Oss West de bewaakte spoorwegovergang op en werd gegrepen door de passerende trein. Vier jonge kinderen kwamen om het leven, een ouder kind en de begeleidster raakten zwaargewond. Op het moment van schrijven van dit artikel is de toedracht nog niet precies bekend, maar de meest gehoorde verklaring is dat de begeleidster er niet in slaagde de Stint tot stilstand te brengen. ${ }^{1}$

Vanzelfsprekend leidde dit ongeval onmiddellijk tot onderzoek naar de oorzaak ervan en de veiligheid van de Stint in het algemeen. ${ }^{2}$ Minister Van Nieuwenhuizen van Infrastructuur en Waterstaat informeerde de Tweede Kamer bij brief van 1 oktober 2018 over de eerste bevindingen. ${ }^{3} \mathrm{Zij}$ deelde mee dat zij op basis daarvan had besloten om de toelating van de Stint op de openbare weg te schorsen. ${ }^{4}$ Dat was een ingrijpende beslissing. Een kleine zeven jaar eerder, bij beschikking van 14 november 2011, was de Stint toegelaten tot het Nederlandse verkeer. ${ }^{5}$ Het voertuig was onmiddellijk een succes. De Stint voorziet in een duidelijke behoefte aan vervoer van kinderen van en naar crèches, gastouders en scholen. De Stint wordt bovendien als betrouwbaar en veilig ervaren: de felgekleurde kuip is goed zichtbaar, de maximumsnelheid is laag

* Mr. C.N.J. Kortmann is advocaat bij Stibbe te Amsterdam en is tevens verbonden aan de Universiteit Utrecht.

De auteur dankt Joëla Schaeffer voor het verzamelen van informatie over de besproken schadefondsen.

1. Zie onder meer de brief van de minister van IenW aan de Voorzitter van de Tweede Kamer van 31 oktober 2018, Kamerstukken II 2018/19, 29398, 617, met bijlagen.

2. Brief van de minister van IenW aan de Voorzitter van de Tweede Kamer van 21 september 2018, Kamerstukken II 2018/19, 29398, 612, met bijlagen.

3. Brief van de minister van IenW aan de Voorzitter van de Tweede Kamer van 1 oktober 2018, Kamerstukken II 2018/19, 29398, 613, met bijlagen.

4. Beschikking van de minister van IenW van 1 oktober 2018, Stcrt. 2018, 56871.

5. Stcrt. 2012,6543 .
$(17 \mathrm{~km} / \mathrm{u})$, en doordat de chauffeur niet zit maar staat, heeft hij beter overzicht dan op de traditionele bakfiets.

Het schorsingsbesluit dupeerde niet alleen de fabrikant van de Stint, die zijn verkoop onmiddellijk zag wegvallen en op 29 oktober 2018 zijn faillissement aanvroeg, ${ }^{6}$ maar ook de vele gebruikers van de Stint. Illustratief is het verzoek van gastouderopvang Het Kinderstraatje te Almere om het besluit van de minister te schorsen, omdat er geen alternatief voor de Stint beschikbaar is. De rechtbank wees dit verzoek af. ${ }^{7}$ Volgens het persbericht is de rechter zich bewust van de nadelige gevolgen voor Het Kinderstraatje, maar mocht de minister het belang van de verkeersveiligheid zwaarder laten wegen en de Stint verbieden tot in elk geval de onderzoeksresultaten bekend zijn. Die worden rond de jaarwisseling verwacht. De minister moet wel voortvarend te werk gaan, zodat betrokkenen niet onnodig lang in onzekerheid hoeven te verkeren, vindt de rechter.

\section{Een kordaat besluit met een fonds als vangnet}

Vlak voordat de rechtbank uitspraak deed, gaf de voorzitter van de Stichting Veiligheid en Maatschappij en oud-voorzitter van de Onderzoeksraad voor Veiligheid, mr. Pieter van Vollenhoven, het interview dat de aanleiding is voor dit artikel. ${ }^{8}$ Hij vindt dat de minister een kordaat besluit heeft genomen, maar dat de belangen van de gedupeerden niet uit het oog moeten worden verloren. Volgens Van Vollenhoven moet er een fonds komen waarop benadeelde partijen een beroep kunnen doen als een besluit van de overheid achteraf te ingrijpend blijkt. Omdat de samenvatting op de NOS-website minder sprekend is dan het interview zelf, laat ik mr. Van Vollenhoven, die in de huid van de minister kruipt, zelf aan het woord:

6. Welk verzoek hij overigens op 6 november 2018 weer introk in afwachting van de lopende procedures.

7. Rb. Midden-Nederland 1 november 2011, ECLI:NL:RBMNE: 2018:5318. Volgens de NOS is Het Kinderstraatje in hoger beroep gegaan: https://nos.nl/artikel/2258174-gastouder-naar-raad-van-state-om -stint-weer-te-mogen-gebruiken.html.

8. Zie https://nos.nl/artikel/2257345-van-vollenhoven-wil-fonds-voorgedupeerden-overheidsbesluiten.html. Men kan zich afvragen of de timing van dit interview, zo vlak voor de uitspraak van de rechter, kies was, maar dat terzijde. 


\section{Maandblad}

\begin{abstract}
'Als je [de minister; CK] dit soort vergissingen uit de weg gaat, dan wordt het heel onveilig. Dus je moet wel de moed hebben om dit soort beslissingen te nemen en dan hoop ik dat er een goede inspectie is die me goed informeert dat alles klopt. (...) Een fonds hoort daarbij, want het kan altijd zo zijn dat je het verkeerd hebt ingeschat en het een te zware beslissing blijkt. Maar voor de veiligheid en de samenleving moeten de minister en de inspectie de moed hebben om dit soort ingrepen te doen, hoe vervelend ze ook zijn. (...) Als een beslissing op verkeerde gronden is gemaakt en je gaat er schade door lijden, dan kan je best een beroep doen op zo'n fonds en dan vind ik het ook juist dat dat dan kan.'
\end{abstract}

Een interessante en sympathieke gedachte, die meteen allerlei vragen oproept. ${ }^{9}$ Wie gaat dit fonds opzetten en financieren? Hoe is de zeggenschap geregeld? Op basis van welke criteria wordt uitgekeerd ${ }^{10} \mathrm{Bij}$ beoefenaren van het overheidsaansprakelijkheidsrecht komen nog principiëlere vragen op: is er eigenlijk sprake van een probleem dat aangepakt moet worden, en zo ja, is het schadefonds Van Vollenhoven daarvoor de goede oplossing? Het zijn deze twee laatste vragen die het onderwerp van dit artikel vormen.

\section{Schadefondsen, een tour d'horizon}

Het instellen van een schadefonds is niet niks. Oprichting en inrichting kosten tijd en geld, en ook met het beheer en de instandhouding van het fonds is meer geld gemoeid dan alleen het bedrag van de uitkeringen. Bovendien is een schadefonds een extra. Het komt boven op de bestaande systemen om benadeelden tegemoet te komen. Voor dat extra kunnen goede redenen zijn, maar het vraagt wel om een stevige onderbouwing. Een minimumeis lijkt mij dat het fonds in een reële behoefte voorziet. Daarom maak ik een korte rondgang langs fondsen die hun bestaansrecht hebben bewezen. Dat kan een indruk geven van de factoren die het schadefonds zijn meerwaarde bezorgen. De focus ligt op permanente, ofwel structurele fondsen. ${ }^{11}$ Het voorstel van Van Vollenhoven lijkt immers een bredere strekking te hebben dan een tijdelijk fonds specifiek voor Stint-gedupeerden. De gehaaste lezer kan zonder verlies van de rode draad doorbladeren naar het slot van deze paragraaf voor de oogst van deze rondgang.

\subsection{Plaatsbepaling}

Van Dale omschrijft het woord fonds als een voor een bijzonder doel vastgelegd kapitaal. In het bijzonder kan het gaan om

9. Zeker na alle moeilijkheden bij de schadeafhandeling in Groningen, waarover hierna meer.

10. Het interview met Van Vollenhoven maakt bijvoorbeeld niet goed duidelijk of alleen wordt uitgekeerd als de overheid - achteraf bezien een fout heeft gemaakt (schadevergoeding), of ook als er sprake is van een op zichzelf juist overheidsbesluit met onevenredige gevolgen (nadeelcompensatie). Over beide opties kom ik nog te spreken.

11. Over tijdelijke fondsen die zijn opgericht na oorlogen, rampen of zware ongevallen, zij de lezer - onder meer - verwezen naar C.J. van Weering, in: Handboek personenschade (losbl.), Alphen aan den Rijn: Kluwer, nr. 3060 (massaschade). een rechtspersoon, bijvoorbeeld een stichting, met het doel om door ingebracht kapitaal aan de deelnemers uitkeringen te doen in bepaalde, voorziene gevallen. Bij een schadefonds is doorgaans inderdaad sprake van rechtspersoonlijkheid. Uitkeringen worden niet zozeer gedaan aan deelnemers, als wel aan een in het reglement van het fonds omschreven kring van benadeelden. Zoals gezegd komt een schadefonds boven op bestaande systemen om benadeelden tegemoet te komen. Vaak functioneert het daar waar het aansprakelijkheidsrecht tekortschiet. Maar het is niet het enige alternatieve vergoedingsmechanisme. Wetgever en openbaar bestuur hebben in de twintigste eeuw voorzien in een waaier van wettelijke en beleidsmatige regelingen om benadeelden van natuurgeweld, ziektes en criminelen, maar ook van overheidsoptreden zelf tegemoet te komen. De voorbeelden van deze laatste categorie liggen voor het oprapen: schadeloosstelling bij onteigening, de wettelijke planschaderegeling, ${ }^{12}$ de Beleidsregel nadeelcompensatie Infrastructuur en Milieu 2014, de Verordening nadeelcompensatie Noord/Zuidlijn, enzovoort. Het schadefonds onderscheidt zich van deze vergoedingsmechanismen doordat sprake is van een afgescheiden vermogen met een eigen doel en uitkeringsregels.

\subsection{Schadefonds Geweldsmisdrijven}

Van de schadefondsen is vermoed ik het meest bekend het Schadefonds Geweldsmisdrijven. Het fonds is ingesteld bij de Wet schadefonds geweldsmisdrijven. Dit fonds is een vangnet voor slachtoffers of nabestaanden wier schade niet op de dader kan worden verhaald. ${ }^{13}$ Deze uitkeringen worden gedaan aan degene die door een geweldsmisdrijf ernstig lichamelijk of geestelijk letsel heeft bekomen of nabestaanden daarvan. ${ }^{14} \mathrm{Het}$ fonds houdt bij de uitkering rekening met de schadevergoeding die het slachtoffer langs de burgerrechtelijke weg kan verhalen of heeft verhaald en de overige vergoedingen van schade. ${ }^{15}$ De uitkering is een maatschappelijke uiting van solidariteit en een blijk van erkenning van het onrecht en leed dat een slachtoffer of nabestaande is overkomen namens de samenleving vanuit de overheid. $\mathrm{Zij}$ wordt betaald uit belastinggeld ${ }^{16}$ en heeft - gelet op het tegemoetkomende karakter - niet tot doel alle schade te dekken. De uitkering is bedoeld om het geschade vertrouwen enigszins te herstellen en het slachtoffer of de nabestaande (financieel) vooruit te helpen, zodat de blik weer op de toekomst kan worden gericht. De ontvanger is vrij in de besteding ervan. De tegemoetkoming bedraagt maximaal $€ 35.000 .{ }^{17}$

Het Schadefonds Geweldsmisdrijven moet niet worden verward met het Fonds Slachtofferhulp. Dit is een onafhankelijke maatschappelijke organisatie, die op basis van de meest dringende vragen uit de samenleving programma's ontwikkelt voor

12. Afdeling $6.1 \mathrm{~W}$ ro.

13. Zie schadefonds.nl/nl/het-schadefonds/organisatie/missie-visie-endoelstellingen.

14. Art. 3 Wet schadefonds geweldsmisdrijven.

15. Art. 6 Wet schadefonds geweldsmisdrijven.

16. Art. 2 Wet schadefonds geweldsmisdrijven.

17. Beleidsbundel Schadefonds Geweldsmisdrijven, mei 2018, p. 4. 
een structureel hulpaanbod aan slachtoffers. De reikwijdte van het fonds is breed: het besteedt aandacht aan slachtoffers van seksueel geweld (middels financiering van het Centrum Seksueel Geweld), verkeersongevallen (onderzoek laten verrichten naar de strafmaat bij verkeersmisdrijven door Tilburg University) en medische incidenten. Daarnaast zijn er nog andere programma's waarin het fonds actief is, zoals geweldsmisdrijven, vermissingen, rampen en noodhulp. Het Fonds Slachtofferhulp werft fondsen om de (rechts)positie van slachtoffers in Nederland te verbeteren en uit te breiden. Het doel is dat het nieuwe hulpaanbod wordt ingebed in de structurele hulp die door de overheid gegeven wordt. Het Fonds Slachtofferhulp is afhankelijk van giften uit de samenleving (sponsoren en donateurs) en krijgt geen geld van de overheid. ${ }^{18}$

\subsection{Waarborgfonds Motorverkeer}

Het Waarborgfonds Motorverkeer is het op de Wet aansprakelijkheidsverzekering motorrijtuigen gebaseerde vangnet voor benadeelden in het verkeer. ${ }^{19}$ Dit vangnet houdt in dat een benadeelde, indien er burgerrechtelijke aansprakelijkheid bestaat voor een door een motorrijtuig veroorzaakte schade, recht heeft op schadevergoeding van het waarborgfonds in de gevallen waarin, kort samengevat, de dader onvindbaar is of de verzekeraar van de dader niet uitkeert. ${ }^{20}$ Het Waarborgfonds Motorverkeer is een door de minister aangewezen privaatrechtelijke rechtspersoon. Het wordt gefinancierd uit jaarlijks vastgestelde bijdragen van Nederlandse motorrijtuigverzekeraars. ${ }^{21}$ Een deel van alle WA-premies voor motorrijtuigen gaat naar het Waarborgfonds Motorverkeer. ${ }^{22}$ De ministeriële aanwijzing is niet vrijblijvend. Zodra de minister van Justitie en Veiligheid en de minister van Financiën oordelen dat het waarborgfonds zijn taak niet meer naar behoren kan vervullen, kunnen zij de aanwijzing intrekken. Dit heeft ontbinding van de rechtspersoon tot gevolg en doet het vermogen van de rechtspersoon onder algemene titel overgaan op de Staat, waarna de ministers zelf voorzien in de taak van het waarborgfonds. $^{23}$

\subsection{Fonds Luchtverontreiniging}

Het Fonds Luchtverontreiniging was een sinds begin jaren zeventig bestaande voorziening voor de vergoeding van schade ten gevolge van incidentele luchtverontreiniging, welke schade moeilijk of niet verhaalbaar is, bijvoorbeeld omdat de veroorzaker van de schade onbekend is of niet aansprakelijk is, dan wel bekend en aansprakelijk is, maar geen of slechts gedeeltelijk verhaal biedt. Het fonds vervulde een vangnetfunctie: geen schadevergoeding werd toegekend indien de schade langs bur-

18. Zie https://fondsslachtofferhulp.nl/veelgestelde-vragen.

19. Zie waarborgfonds.vereende.nl/de-organisatie. Zie art. 23-27 WAM.

20. Bijv. omdat de WAM-verzekeringsplicht niet is nagekomen, dan wel de verzekeraar zich op een uitsluiting kan beroepen (zoals bij joyriding) of insolvent is geraakt.

21. In het fonds worden ook de bijdragen gestort van degenen die wegens gemoedsbezwaren zijn vrijgesteld van verzekeringsplicht. Zie art. 22 WAM.

22. Zie waarborgfonds.vereende.nl/de-organisatie.

23. Art. 23 WAM. gerrechtelijke weg was of kon worden verhaald. ${ }^{24}$ Het fonds is opgeheven in $2007 . .^{25}$ Dit hing samen met de totstandkoming van een algemene milieuschaderegeling die, zo was toen de verwachting, nodig zou zijn voor de implementatie van de Europese richtlijn milieuaansprakelijkheid. Inmiddels is deze richtlijn vastgesteld. ${ }^{26}$ In tegenstelling tot eerdere verwachtingen vloeit uit deze richtlijn voor de overheid geen verplichting voort om een vangnet in het leven te roepen voor de financiering van het herstel van niet-verhaalbare milieuschade. ${ }^{27}$ Het fonds had weliswaar rechtspersoonlijkheid, maar verder was het - afgezien van het afgescheiden vermogen - in feite een onderdeel van het ministerie van Volkshuisvesting, Ruimtelijke Ordening en Milieubeheer (VROM). De minister beheerde het fonds en besliste over de uitkeringen ervan op basis van de wet en het Besluit Fonds Luchtverontreiniging.

\subsection{Faunafonds}

Het Faunafonds had onder meer tot taak het verlenen van tegemoetkomingen in geleden schade (nadeelcompensatie), aangericht door dieren behorende tot beschermde inheemse diersoorten. $^{28}$ Een tegemoetkoming werd slechts verleend 'voor zover een belanghebbende schade lijdt of zal lijden aangericht door dieren, behorende tot een beschermde inheemse diersoort, en die schade redelijkerwijs niet of niet geheel te zijnen laste behoort te blijven'. Het bestuur van het fonds was onafhankelijk en werd geworven uit de kringen van jacht, landbouw, natuurbescherming en dierenwelzijn. Het fonds werd gefinancierd door provincies en het Rijk. ${ }^{29}$ Met de inwerkingtreding van de Wet natuurbescherming per 1 januari 2017 is het Faunafonds opgeheven. Het verstrekken van nadeelcompensatie vanwege faunaschade is gedecentraliseerd naar de provincies.

\subsection{Olieschadefonds}

Het Olieschadefonds is ingesteld bij de Wet schadefonds olietankschepen in uitvoering van het Internationaal Verdrag betreffende de instelling van een Internationaal Fonds voor vergoeding van schade door verontreiniging door olie. ${ }^{30} \mathrm{Het}$ doel van dit fonds is om vergoeding te verschaffen voor schade door verontreiniging voor zover het parallel gesloten Aansprakelijkheidsverdrag ${ }^{31}$ onvoldoende bescherming biedt. ${ }^{32}$ Het fonds wordt gefinancierd uit bijdragen van zogenaamde 'grote ontvangers van bijdragende olie'. 33

24. Art. $15.26 \mathrm{Wm}$ (oud).

25. Stb. 2007, 427.

26. Richtlijn 2004/35/EG betreffende milieuaansprakelijkheid met betrekking tot het voorkomen en herstellen van milieuschade.

27. Kamerstukken II 2005/06, 29383, 38.

28. Art. 83-100 Flora- en faunawet (oud).

29. Ook wordt van houders van jachtakten e.d. een bijdrage geheven ten behoeve van het Faunafonds.

30. Trb. 1994, 228.

31. Trb. 1994, 229.

32. Art. 2 Verdrag.

33. Zie art. 10 Verdrag. Het gaat om rechtspersonen die per jaar meer dan 150.000 ton olie ontvangen die over zee is vervoerd. 


\subsection{Waarborgfonds mijnbouwschade}

Het Waarborgfonds mijnbouwschade (of korter: het mijnbouwfonds) is ingesteld op grond van art. 135 van de Mijnbouwwet. Schadevergoeding ten laste van het waarborgfonds wordt toegekend aan een natuurlijke persoon bij wie zaakschade is opgetreden als gevolg van mijnbouwactiviteiten, indien, kort samengevat, de betrokken mijnbouwondernemer niet meer bestaat of geen verhaal biedt. ${ }^{34}$ Het mijnbouwfonds heeft rechtspersoonlijkheid, maar is overigens een verlengstuk van het ministerie van Economische Zaken en Klimaat (EZK). De minister beheert het fonds, verstrekt de uitkeringen ten laste van het fonds en heft van mijnbouwondernemers krachtens het Mijnbouwbesluit bijdragen ter financiering van het fonds.

\subsection{Nationaal Rampenfonds}

Het Nationaal Rampenfonds (NRF) is opgericht in 1935. In het NRF nemen het Rode Kruis, Kerk in Actie, Cordaid en Het Oranje Kruis deel. Het NRF stelt zich ten doel 'door het bijeenbrengen van gelden en goederen bij te (doen) dragen aan leniging van de noden, ontstaan door rampen, die de bevolking van enig deel van het Koninkrijk der Nederlanden treffen en die van zodanige aard en omvang zijn, dat zij, naar het oordeel van het bestuur, als nationale rampen moeten worden beschouwd'. Het doet dit onder meer door het verstrekken van bijdragen aan rechtspersonen (waaronder maatschappelijke organisaties) die daartoe vanwege hun doelstelling en activiteiten, organisatie en kwaliteit naar het oordeel van de door het algemeen bestuur ingestelde beoordelingscommissie in staat worden geacht. ${ }^{35}$ Het vermogen van de stichting wordt gevormd door giften, erfstellingen en legaten en inkomsten uit het vermogen van de stichting. ${ }^{36}$ Het NRF verleent sinds 2015 geen bijdragen meer aan individuele slachtoffers van rampen. De laatste keer dat het NRF uitkeringen heeft gedaan, is aan slachtoffers van de Vuurwerkramp in Enschede in 2000. ${ }^{37}$

Het NRF komt in actie als zich een ramp voordoet die door het bestuur van het NRF als 'nationale ramp' wordt gekwalificeerd, na afstemming met de rijksoverheid. Deze afstemming heeft een wederzijds karakter, want als zich een ramp voordoet, zal de regering moeten beoordelen of deze wordt aangemerkt als een ramp in de zin van de Wet tegemoetkoming schade bij rampen. Deze wet, ingesteld na de aardbeving bij Roermond in 1992 en de overstromingen van de Maas in 1993 en 1995, is van toepassing op zoetwateroverstromingen, aardbevingen en andere bij koninklijk besluit aan te wijzen

\footnotetext{
34. Art. 137 Mijnbouwwet.

35. Art. 2 Statuten d.d. 2017.

36. Art. 3.1 Statuten d.d. 2017.

37. Bron: www.nationaalrampenfonds.nl.
}

rampen. ${ }^{38} \mathrm{Zij}$ voorziet in een tegemoetkoming in een limitatieve lijst van schadesoorten. ${ }^{39} \mathrm{Er}$ is geen apart fonds ingesteld ter uitvoering van deze wet. ${ }^{40}$

\subsection{Oogst}

Overziet men deze rondgang door het landschap van permanente schadefondsen, dan vertoont zich een breed spectrum. Naast de overheidsfondsen hebben particulier gefinancierde en bestuurde schadefondsen een aanzienlijke rol in de slachtofferhulp. En ook binnen de overheidsfondsen is de variatie groot: van verlengstukken van een ministerie tot tamelijk zelfstandig opererende organisaties. ${ }^{41}$ De schadefondsen kunnen voorzien in afwikkeling van individuele schades, maar ook van massaschades. Bekijkt men echter het doel van deze fondsen, hun bestaansrecht, dan is het beeld minder gevarieerd. Alle fondsen hebben een vangnetfunctie. ${ }^{42}$ Schiet het gewone aansprakelijkheidsrecht tekort, dan - en alleen dan - kan op het fonds een beroep worden gedaan. Dat tekortschieten kan gelegen zijn in een onvindbare of insolvente dader, of in het ontbreken van aansprakelijkheid.

Men zou kunnen zeggen dat de besproken fondsen alle zijn geënt op het beginsel van solidariteit. Dat geldt ook voor het schadefonds Van Vollenhoven. Maar daarmee houdt de gelijkenis met de andere fondsen wel op. Van een onvindbare of insolvente dader is bij het schadefonds Van Vollenhoven geen sprake. Integendeel, de Nederlandse Staat kan wel worden beschouwd als de meest vindbare en solvente dader denkbaar. Het fonds voorziet ook niet in situaties waarin de overheid juridisch niet aansprakelijk is. Van Vollenhoven spreekt immers over een overheidsbeslissing die op verkeerde gronden is gemaakt en schade veroorzaakt. In dat geval kan de Staat worden aangesproken uit onrechtmatige daad en is het schadefonds Van Vollenhoven als vangnet overbodig. Ik zou dit artikel op deze plaats dus kunnen besluiten met de conclusie dat Van Vollenhoven een sympathiek en origineel idee te berde heeft gebracht, maar zijn schadefonds een probleem probeert op te lossen dat er niet is en het geld dus beter aan andere schadefondsen kan worden besteed. Ik doe dat niet. Want mis-

38. Art. 3 Wet tegemoetkoming schade bij rampen. De vraag naar de noodzaak (en zelfs rechtsplicht) tot oprichting van een structureel overheidsrampenfonds is onderzocht door J. van de Bunt, Het rampenfonds (diss. Leiden), Deventer: Wolters Kluwer 2016. Zij beantwoordt deze vraag bevestigend. M. Tjepkema, Tegemoetkomingen van overheidswege: ongeregeld en ondoorzichtig bestuur anno 2014, NTB 2014/3, gaat nog een stap verder met zijn betoog dat alle permanente en tijdelijke schadefondsen en -uitkeringen regeling in de Awb en kaderwetten verdienen, analoog aan het subsidierecht. Met W. den Ouden \& S. Zijlstra, die ook al eerder in gelijke zin publiceerden, heeft hij deze gedachte uitgewerkt in: De tegemoetkoming geregeld, NTB 2015/13.

39. Deze lijst is bij ministeriële regeling uit te breiden, met uitzondering van omzetschade. Zie over de uitbreiding tot personenschade E.F.D. Engelhard \& R. Rijnhout, Een regeling voor personenschade door rampen, Den Haag: Boom juridisch 2015.

40. Dat is overigens geenszins uniek, zo bleek al in par. 3.1.

41. Het Waarborgfonds Motorverkeer is een echte hybride tussenvorm: een privaat fonds, dat wat betreft status, financiering en beheer sterk publiekrechtelijk is ingekaderd.

42. Dat geldt ook voor de Wet tegemoetkoming schade bij rampen, vgl. Engelhard \& Rijnhout 2015, p. 13. 


\section{Maandblad}

Vermogensrecht

schien heeft Van Vollenhoven wel bedoeld dat het in de praktijk uiterst lastig en kostbaar is om schadeclaims tegen de Nederlandse Staat te effectueren, en heeft hij daarvoor een voorziening willen treffen. En dan heeft hij een punt. Ik zal dat aan de hand van de Stint-casus laten zien en besluiten met een aantal kenmerken waaraan mijns inziens het schadefonds Van Vollenhoven moet voldoen om dit probleem effectief aan te pakken.

\section{Knelpunten bij afwikkeling van besluitenaansprakelijkheid}

De kern van de boodschap van Van Vollenhoven is dat de minister de moed moet hebben om pijnlijke besluiten te nemen met het oog op de veiligheid, maar dat als zo'n besluit achteraf bezien een te zware beslissing blijkt te zijn geweest, de gedupeerden aanspraak moeten kunnen maken op compensatie. In de vorige paragraaf concludeerde ik dat het niet per se nodig is daarvoor een schadefonds in de gebruikelijke zin van het woord op te richten, omdat er in principe geen behoefte is aan een vangnet: het gewone aansprakelijkheidsrecht voorziet in een recht op compensatie als de overheid fouten maakt. De reden om toch een schadefonds op te richten zou dus gelegen moeten zijn in het tekortschieten van het aansprakelijkheidsrecht, met name de compenserende functie ervan. Dit tekortschieten kan zich op het inhoudelijke vlak en het procedurele vlak voordoen.

\subsection{Inhoudelijke hobbels}

Neemt de minister een 'te zware beslissing', dan ligt het het meest voor de hand hem ${ }^{43}$ aan te spreken uit onrechtmatige daad. Omdat de schorsing van de toelating van de Stint tot het Nederlandse verkeer een appellabele beschikking is, zal de bestuursrechter de onrechtmatigheid daarvan moeten vaststellen. Dat is op zichzelf al niet eenvoudig, omdat de schorsingsbevoegdheid een ongeschreven, discretionaire bevoegdheid is. ${ }^{44} \mathrm{Bij}$ gebrek aan een wettelijk toetsingskader zal de gedupeerde moeten aantonen dat met de beschikking een algemeen beginsel van behoorlijk bestuur is geschonden. Het zorgvuldigheidsbeginsel en het evenredigheidsbeginsel liggen daarbij het meest voor de hand. ${ }^{45}$ Daarbij toetst de bestuursrechter $e x$ tunc. Ook als de beschikking achteraf bezien 'een te zware beslissing' zou blijken, dan is er een gerede kans dat de bestuursrechter (net als de voorzieningenrechter op het verzoek van Het Kinderstraatje) oordeelt dat de minister op 1 oktober 2018, zo kort na de ramp, het veiligheidsbelang het zwaarst mocht laten wegen. Relevantere rechtsvragen zouden wel eens kunnen zijn of de minister het schorsingsbesluit

43. Ik kies er kortheidshalve voor om de minister als het betrokken rechtssubject aan te merken. Vgl. art. 8:88 Awb. In een procedure voor de burgerlijke rechter is dat de Nederlandse Staat. Zie uitgebreider over dit onderscheid N. Jak \& C.N.J. Kortmann, Procesbevoegdheid van de overheid in een burgerlijk geding. Rechtspersoon of bestuursorgaan?, NTB $2017 / 40$.

44. Vgl. r.o. 7 van de al in noot 7 genoemde uitspraak Rb. Midden-Nederland 1 november 2011, ECLI:NL:RBMNE:2018:5318 (Het Kinderstraatje).

45. Art. 3:2 en 3:4 Awb. mocht nemen zonder een financiële tegemoetkoming (al dan niet in de vorm van een voorschot) aan de fabrikant, ${ }^{46}$ en hoelang de minister de schorsing mocht laten voortduren. De gedupeerden (en hun advocaten) moeten goed zijn ingevoerd in het bestuursrecht en het overheidsaansprakelijkheidsrecht om hierin de juiste processtrategie te kiezen. Bovendien lopen zij het risico dat zij hun rechten verspelen door het leerstuk van de formele rechtskracht. Vechten zij het schorsingsbesluit niet of zonder succes aan, dan wordt dit in een schadevergoedingsprocedure voor rechtmatig gehouden. ${ }^{47}$ Voor zover mij bekend heeft alleen Het Kinderstraatje het schorsingsbesluit in rechte aangevochten. Zou Het Kinderstraatje in de bodemzaak uiteindelijk in het gelijk worden gesteld met wijziging of herroeping van het schorsingsbesluit tot gevolg, dan zijn de andere gedupeerden daarmee nog geen stap verder. Jegens hen wordt het schorsingsbesluit namelijk nog steeds voor rechtmatig gehouden. Zij kunnen in het besluitenaansprakelijkheidsrecht niet profiteren van het succes van Het Kinderstraatje. ${ }^{48}$ Voor Het Kinderstraatje zelf geeft succes bij de bestuursrechter overigens evenmin een garantie op schadevergoeding. De eerstvolgende hobbel zal vermoedelijk de relativiteitsleer zijn. Immers, beschermt de regeling voor toelating van voertuigen tot het Nederlandse verkeer tegen schade van een gastouderopvang die extra kosten moet maken van alternatief vervoer voor de kinderen? Dat is maar zeer de vraag. ${ }^{49}$

De benadeelden die het schorsingsbesluit niet aanvochten, zouden eventueel een zogenaamd nadeelcompensatieverzoek kunnen doen. $\mathrm{Zij}$ zouden daaraan ten grondslag kunnen leggen dat het schorsingsbesluit vanwege het zwaarwegende veiligheidsbelang weliswaar rechtmatig was, maar zij op grond van het beginsel van de gelijkheid voor de openbare lasten recht hebben op een tegemoetkoming in hun schade (nadeelcompensatie). ${ }^{50}$ De benadeelden kiezen dan voor een wezenlijk andere grondslag voor aansprakelijkheid, maar de inhoudelijke hobbels zijn op deze weg zeker niet minder hoog. ${ }^{51}$ En slaagt een dergelijk verzoek, dan zal dit niet leiden tot volledi-

46. Een zogenaamd onzelfstandig schadebesluit.

47. Vaste jurisprudentie, ingezet met het arrest HR 16 mei 1986, NJ 1986/723 m.nt. MS (Heesch/Van de Akker).

48. Vaste jurisprudentie sinds HR 19 juni 1998, NJ 1998/869 m.nt. MS (Kaveka).

49. Art. 2 WVW 1994 noemt vele doelstellingen, maar niet het voorkomen van extra kosten van instellingen die afhankelijk zijn van bijzonder vervoer. Dat is voor Het Kinderstraatje geen goed begin. Vgl. P.W. den Hollander, De relativiteit van wettelijke normen, Den Haag: Boom juridisch 2016, par. 5.13 en 6.7, en L. Di Bella, De toepassing van de vereisten van causaliteit, relativiteit en toerekening bij de onrechtmatige overheidsdaad, Deventer: Kluwer 2014, par. 5.2.

50. Vgl. onder veel meer M.K.G. Tjepkema, Nadeelcompensatie op basis van het égalitébeginsel, Deventer: Kluwer 2010.

51. Een korte blik op artikel 4:126 Awb maakt dat duidelijk. Het artikel is nog niet van kracht, maar wel aangenomen en gepubliceerd (als onderdeel van de Wet nadeelcompensatie en schadevergoeding bij onrechtmatige besluiten, Stb. 2013, 50) en het vat de rechtspraak over aansprakelijkheidsverminderingsgronden goed samen. 
ge schadevergoeding, maar tot een tegemoetkoming in de schade, voor zover deze als onevenredig wordt beschouwd. ${ }^{52}$

\subsection{Procedurele belemmeringen}

Iedereen die in het aansprakelijkheidsrecht actief is, weet dat schadeprocedures, en zeker procedures tegen de Nederlandse Staat, notoir lang duren. ${ }^{53}$ Zelfs als de gedupeerde de inhoudelijke hobbels uit de vestigingsfase van de aansprakelijkheid heeft genomen, kan het debat over de omvang van de schadevergoedingsverbintenis moeizaam en kostbaar zijn. Causaal verband, eigen schuld en begroting van de schade ${ }^{54}$ zijn leerstukken die geliefd zijn bij aansprakelijkheidsjuristen, maar op weinig sympathie van benadeelden kunnen rekenen. Gastouderopvang Het Kinderstraatje zal vermoedelijk niet de middelen en het uithoudingsvermogen hebben om zijn eventuele claim tot het eind toe uit te procederen. Dat zou mogelijk anders komen te liggen als alle kinderopvangvoorzieningen zich verenigen en gebruik maken van de voorzieningen van de Wet collectieve afwikkeling massaschade (WCAM). ${ }^{55}$ Maar zoals wij in de vorige paragraaf al zagen, in de Stint-casus biedt die wet vermoedelijk geen soelaas vanwege het leerstuk van de formele rechtskracht.

\subsection{Schadefonds gaswinning Groningen}

In het licht van de beschreven materiële en procedurele moeilijkheden in het gewone aansprakelijkheidsrecht is het voorstel van Van Vollenhoven niet alleen origineel, maar misschien ook wel heel goed of zelfs gewoon nodig. De timing van Van Vollenhoven is in elk geval goed, ${ }^{56}$ want er is op dit moment zeer veel aandacht voor een andere zaak waarin het gewone aansprakelijkheidsrecht tekort heeft geschoten, de Groninger gaswinning. En daar lijkt nu het eerste structurele schadefonds van de grond te komen dat niet een vangnetfunctie heeft, maar een alternatief moet bieden voor de afwikkeling via de rechter. $^{57}$

Op 3 juli 2018 is het wetsvoorstel Instituut Mijnbouwschade Groningen in consultatie gegaan. ${ }^{58}$ Met dat wetsvoorstel geeft de regering uitvoering aan het regeerakkoord 2017 'Vertrou-

52. De zogenaamde aftrek wegens normaal maatschappelijk of ondernemersrisico maakt de uitkomst van nadeelcompensatieprocedures notoir lastig te voorspellen.

53. Van de Bunt (2016) beschouwt dit, samen met onvindbaarheid of insolventie van de dader, als het belangrijkste knelpunt van het gewone aansprakelijkheidsrecht. Zie par. 11.1 en 12.3 .

54. Art. 6:97, 6:98 en 6:101 BW.

55. Wet van 23 juni 2005, Stb. 2005, 340, gewijzigd bij wet van 26 juni 2013 , Stb. 2013, 255.

56. En dan spreek ik niet over dag en uur. Zie noot 8 .

57. Zoals gezegd, tijdelijke fondsen ter afwikkeling van massaschades kennen wij wel. Het gaat met name om rampenfondsen (Legionella in Bovenkarspel, Vuurwerkramp Enschede, Dijkdoorbraak Wilnis, Asbestfonds). Zie Van de Bunt 2016, deel III.

58. Zie www.internetconsultatie.nl/instituutmijnbouwschadegroningen. Uitvoerig hierover $\mathrm{H}$. Bröring, Het concept-wetsvoorstel Wet Instituut Mijnbouwschade Groningen, NTB 2018/58. (Het wetsvoorstel Instituut Mijnbouwschade Groningen zal uitgebreid worden besproken door mr. J.E. van de Bunt in het februarinummer van het Maandblad voor Vermogensrecht, als eerste artikel in een serie 'Aardbevingen in Groningen en het vermogensrecht' [red.].) wen in de toekomst'. Daarin is opgenomen dat er onder onafhankelijke publieke regie een schadefonds komt voor de afhandeling van verzoeken om vergoeding van schade als gevolg van bodembeweging door de aanleg of exploitatie van een mijnbouwwerk ten behoeve van gaswinning uit het Groningenveld of gasopslag bij Norg. Art. 2 van dit wetsvoorstel bepaalt, kort samengevat, dat het Instituut tot taak heeft (en bij uitsluiting bevoegd is) om te beslissen op verzoeken om vergoeding van schade die is ontstaan door bodembeweging als gevolg van de gaswinning uit het Groningenveld. Het Instituut is voorts bevoegd om de vastgestelde vergoeding aan de aanvrager uit te keren. Het Instituut vervult zijn taken in onafhankelijkheid ${ }^{59}$ en bestaat uit drie tot vijf leden, die deskundig en onpartijdig zijn. ${ }^{60} \mathrm{Zij}$ worden benoemd, geschorst en ontslagen bij koninklijk besluit, net als rechters. Voor het overige is het Instituut een verlengstuk van het ministerie van EZK. ${ }^{61}$ Dit ministerie stelt (aan het bureau van) het Instituut voldoende financiële middelen en (gekwalificeerd) personeel ter beschikking. ${ }^{62}$ De minister kan de kosten van het Instituut $^{63}$ via een heffing doorbelasten aan de exploitanten van het Groningenveld. ${ }^{64}$

In wezen zal het Instituut optreden als een soort (middellijke) wettelijke vertegenwoordiger van de exploitanten van het Groningenveld, die normaal gesproken op grond van art. 6:177 van het Burgerlijk Wetboek (BW) aansprakelijk zouden zijn. Aan dit artikel wordt dan ook een achtste lid toegevoegd, dat de Wet Mijnbouwschade Groningen van toepassing verklaart op de afhandeling van de in art. 6:177 BW bedoelde mijnbouwschade, voor zover deze 'Gronings' is. ${ }^{65}$ Deze kanalisering naar het Instituut is exclusief: de burgerlijke rechter dient een schadevordering niet-ontvankelijk te verklaren als, kort samengevat, het Instituut de betreffende schade kan afwikkelen. ${ }^{66}$

Totdat er een onafhankelijk schadefonds onder publieke regie is ingericht, functioneert sinds 19 maart 2018 de Tijdelijke Commissie Mijnbouwschade Groningen. Deze commissie is in het leven geroepen om afhankelijke beslissingen te nemen over schadeoorzaken en de bijbehorende vergoeding. De onafhankelijkheid van de commissie is van groot belang voor de geloofwaardigheid van het nieuwe stelsel en voor het vertrouwen van burgers in de schadeafhandeling. Om die reden opereert zij niet alleen volledig onafhankelijk van de NAM, maar in de afhandeling van individuele schadegevallen ook op afstand van het kabinet: de commissie beoordeelt individuele

59. Art. 2 lid 2 wetsvoorstel.

60. Art. 3 wetsvoorstel.

61. Zoals de MvT op art. 4 terecht vermeldt, de constructie doet denken aan die van de Autoriteit Consument en Markt en de Autoriteit Nucleaire Veiligheid.

62. Art. 4 en 13 wetsvoorstel.

63. Met enkele uitzonderingen, zoals beheerskosten.

64. Art. 14 wetsvoorstel. In concreto zullen de lasten worden gedragen door de NAM en haar aandeelhouders, ExxonMobil, Shell en de Staat.

65. Art. 24 wetsvoorstel.

66. Art. 16 wetsvoorstel. Juister zou het overigens zijn als de wettekst zou spreken van het niet-ontvankelijk verklaren van de eiser in zijn vordering. 


\section{Maandblad \\ Vermogensrecht}

zaken op inhoudelijke gronden. ${ }^{67}$ Het spreekt voor zich dat deze criteria ook voor het op te richten Instituut zullen moeten gelden. Alleen dan zal het vertrouwen van de Groningers op een onafhankelijke, onpartijdige, effectieve en rechtvaardige schadeafwikkeling kunnen worden gewonnen. ${ }^{68}$

\section{Het schadefonds Van Vollenhoven}

Bij nader inzien zit er wel muziek in het schadefonds Van Vollenhoven. Niet in de traditionele zin, als vangnet voor zaken waarin er geen aansprakelijke en solvente dader kan worden gevonden, maar als alternatief voor de moeizame en kostbare procedure bij de rechter. ${ }^{69}$ Zo'n fonds heeft mijns inziens alleen zin als het ook daadwerkelijk voordelen biedt ten opzichte van de gerechtelijke procedure, zodanig dat het de moeite en kosten van de oprichting en het beheer van het fonds kan rechtvaardigen. Ik denk dat dat een behoorlijke dosis moed van de overheid vraagt. ${ }^{70}$ Een snelle en ruimhartige afwikkeling van schadeclaims, zoals die in de Stint-zaak, betekent het loslaten van gevestigde leerstukken van formele rechtskracht en relativiteit, ${ }^{71}$ ten faveure van een concrete en eenduidige omschrijving van de kring van gerechtigden, de vergoedbare schadesoorten, de schadebegroting en eventuele andere voorwaarden aan uitkeringen. ${ }^{72}$ Verkorting van de procedure en beperking van de daarmee gemoeide kosten kunnen worden bereikt als het schadefonds erin slaagt om met een goed gestroomlijnde procedure tot beslissingen te komen die in hoge mate geaccepteerd worden. Dat zal in de praktijk ten minste betekenen dat het fonds bestuurd en beheerd wordt door onpartijdige, hooggekwalificeerde (en dus dure) mensen met een goed uitgeruste ondersteuning. Uit institutioneel oogpunt kan het schadefonds gaswinning Groningen dus goed model staan voor het schadefonds Van Vollenhoven. Of het overigens een goede inspiratiebron is, zal de toekomst moeten uitwijzen. Evident is dat niet: de overheidsinvloed in het Groningse fonds is sterk, de inhoudelijke criteria voor aansprakelijkheid verschillen niet ten opzichte van die van art. 6:177 $\mathrm{BW}$, en de procedurele weg is ook voor de Groningers lang. Mocht Van Vollenhoven draagvlak vinden voor zijn voorstel, dan zou dat een goede gelegenheid zijn om het in Groningen geleerde in de praktijk te brengen.

Met deze conclusie heb ik misschien wel de moeilijkste vraag rond het schadefonds Van Vollenhoven omzeild. Dat is de

67. Kamerstukken II 2017/2018, 33529, 423, p. 3 en 5 .

68. Het gaat hier om noodzakelijke, maar niet per se voldoende criteria om dat vertrouwen terug te winnen. Vgl. G.M. Kuipers \& M.K.G. Tjepkema, 'Publieke regie' in Groningen, NJB 2017/1576, die een aanpak bepleiten die rekenschap geeft van inzichten uit de sociale psychologie.

69. Of rechters, als de schadeoorzaak een appellabel besluit is.

70. In het Groningse dossier heeft de Tweede Kamer (ten langen leste) die moed getoond door een motie aan te nemen die niet een technisch-juridische afhandeling bepleit, maar een ruimhartige en menselijke houding als uitgangspunt stelt. Kamerstukken II 2016/17, 33529, 346.

71. Of verdergaand: het geheel abstraheren van de normatieve beoordeling van het overheidsoptreden, waarmee ook het onderscheid tussen aansprakelijkheid uit rechtmatige en uit onrechtmatige daad verdwijnt. Vgl. Van de Bunt 2016, par. 10.3.2.4.

72. Vergelijkbare criteria gelden - niet toevallig - ook voor de vaststellingsovereenkomst als bedoeld in de WCAM, zie art. 7:907 BW. vraag, die in Groningen niet of veel minder speelt, naar de reikwijdte van het fonds. Komt het schadefonds alleen in actie als de schade is veroorzaakt door acute overheidsmaatregelen ter bescherming van de veiligheid van mensen? En waarom dan wel en anders niet? Wat rechtvaardigt dat gedupeerden van dit type overheidsoptreden een preferente schadeafwikkeling krijgen ten opzichte van benadeelden van ander overheidsoptreden? Deze vraag is nog pregnanter als het schadefonds een overheidsfonds is. Immers, dan zou al snel de indruk kunnen ontstaan dat de overheid een bepaalde groep claimanten voortrekt, bijvoorbeeld om partijpolitieke of mediagenieke redenen, terwijl zij de minder 'sexy' eisers laat verdrinken in het moeras van de traditionele procedure bij de rechter. Wil men een legitiem en gerespecteerd schadefonds Van Vollenhoven, dan zal het op zodanige wijze moeten worden opgericht en ingericht, dat het qua onafhankelijkheid en onpartijdigheid boven elke twijfel is verheven. Voor de wetenschap ligt hier een schone taak. 